\title{
Pretreatment with Allura Red or Tartrazine Increase Resistance of E. coli and Staphylococcus aureus to some Preservatives
}

\author{
Bayan M. Abu-Ghazaleh \\ Department of Biology and Biotechnology, Faculty of Science, Hashemite University, Zarqa, Jordan.
}

\begin{abstract}
Coloring agents such as allura red and tartrazine are frequently used in food and pharmaceutical industries. Also, many types of preservatives are added to food and pharmaceutical products to prevent their spoilage. This study examined the effect of pretreatment with nutrient broth containing allura red (AR) or tartrazine (TA) on survival of $E$. coli and Staphylococcus aureus in media containing preservatives (eg ascorbic acid, citric acid, or sodium chloride). Pretreatment of $E$. coli for 4 days with AR or TA before exposure for 3 days to nutrient broth containing $\mathrm{NaCl}(20 \%)$ significantly increased its resistance to sodium chloride (20\%). Pretreatment of $E$. coli for 4 days with AR, TA, or nutrient broth alone before exposure for 3 days to nutrient broth containing ascorbic acid (1\%) or to nutrient broth containing citric acid $(0.5 \%)$ killed all cells. For $S$. aureus, pretreatment with AR or TA before exposure for 3 days to nutrient broth containing citric acid $(0.3 \%)$ significantly increased its resistance to citric acid $(0.3 \%)$. Pretreatment of $S$. aureus for 4 days with AR, TA, or nutrient broth alone before exposure for 3 days to nutrient broth containing citric acid $(0.3 \%)$ reduced number of cells by $4.37,2.54$, and 6.97 logs, respectively. Pretreatment of $S$. aureus for 4 days with AR, TA, or nutrient broth alone before exposure for 3 days to nutrient broth containing ascorbic acid (0.5\%) reduced number of viable cells by $3,3.6$, and 3.07 logs, respectively. Pretreatment of $S$. aureus for 4 days with AR, TA, or nutrient broth alone before exposure for 3 days to nutrient broth containing $\mathrm{NaCl}(20 \%)$ increased number of cells by 0.74 , 0.7 and 1.1logs, respectively. These results have implications in food and pharmaceutical industries.
\end{abstract}

Keywords: Allura red, tartrazine, S. aureus, E. coli, preservatives

\footnotetext{
*Correspondence: bay.ghaz@yahoo.com

(Received: November 18, 2021; accepted: January 4, 2022)

Citation: Abu-Ghazaleh BM. Pretreatment with Allura Red or Tartrazine Increase Resistance of E. coli and Staphylococcus aureus to some Preservatives. J Pure Appl Microbiol. 2022;16(1):389-393. doi: 10.22207/JPAM.16.1.33

(C) The Author(s) 2022. Open Access. This article is distributed under the terms of the Creative Commons Attribution 4.0 International License which permits unrestricted use, sharing, distribution, and reproduction in any medium, provided you give appropriate credit to the original author(s) and the source, provide a link to the Creative Commons license, and indicate if changes were made.
} 


\section{INTRODUCTION}

Allura red and tartrazine are synthetic azo dyes that are used widely in food industry. They are used to give red or yellow color to food or pharmaceutical products. ${ }^{1}$ They are added to many types of food such as jellies, pudding, sweets, soft drinks, fruit juices, chips, dairy products, frozen meat, fish and seafood. ${ }^{2,3}$

Staphylococcus aureus is one of the common causes of foodborne diseases in developed and developing countries. ${ }^{4}$ Symptoms of food poisoning result from consumption of preformed enterotoxin(s) that are produced in the food contaminated with S. aureus. ${ }^{5}$ Many strains of E. coli are pathogenic causing mild or severe diarrhea. Food poisoning outbreaks usually result from ingestion of fresh vegetables or fruits or undercooked food contaminated with these microorganisms. ${ }^{6}$

Chemical preservatives are frequently added to food to prevent their spoilage. To my knowledge, there are no studies on the effect of pretreatment with coloring agents (such as allura red, tartrazine) on subsequent inhibition of $S$. aureus and $E$. coli by preservatives. Therefore, this study was undertaken to investigate the effect of pretreatment with allura red or tartrazine on the growth of $S$. aureus and $E$. coli in media containing preservatives (eg ascorbic acid, citric acid, or sodium chloride).

\section{MATERIALS AND METHODS Strains of bacteria}

Strains of E. coli and S. aureus a were obtained from a central laboratory. For preparation of the inoculum, nutrient broth $(20 \mathrm{~mL})$ was inoculated with appropriate cultures and incubated at $31^{\circ} \mathrm{C}$ for $20 \mathrm{~h}$.

\section{Experimental design \\ Growth in nutrient broth}

A $0.5 \mathrm{~mL}$ of the overnight grown bacterial culture was transferred to $10 \mathrm{~mL}$ nutrient broth containing $0.1 \%$ allura red or $0.1 \%$ tartrazine (these concentrations are representatives of the concentrations of AR or TA that may be added to food or pharmaceutical products), and incubated for 4 days at $31^{\circ} \mathrm{C}$. Then $0.5 \mathrm{~mL}$ of each culture was added to $10 \mathrm{~mL}$ nutrient broth containing $\mathrm{NaCl}$ (20\%), or nutrient broth containing ascorbic acid ( $0.5 \%$ or $1 \%)$, or nutrient broth containing citric acid $(0.3 \%$ or $0.5 \%)$. At time 0 and after 1 day and 3 days, samples were withdrawn and appropriate dilutions were made. To enumerate bacterial cells, dilutions were plated on nutrient agar, and plate counts were recorded after incubation at $31^{\circ} \mathrm{C}$ for $24 \mathrm{~h}$. The lower limit of detection for this method was $10 \mathrm{CFU} / \mathrm{mL}$.

For control experiments, $0.5 \mathrm{~mL}$ of the overnight grown bacterial culture was transferred to $10 \mathrm{~mL}$ nutrient broth alone and incubated for 4 days at $31^{\circ} \mathrm{C}$. Then, $0.5 \mathrm{~mL}$ of the culture was added to $10 \mathrm{~mL}$ nutrient broth containing the preservatives as described above. At time 0 and after 1 day and 3 days, samples were withdrawn and treated as previously described to enumerate bacterial cells.

\section{Growth in fish homogenate}

Fish homogenate was prepared and sterilized as previously described. ${ }^{7}$ Then, $10 \mathrm{~mL}$ portion of the cooled homogenate was dispensed into flasks, and allura red $(0.1 \%)$ or tartrazine $(0.1 \%)$ was added to flasks. A $0.5 \mathrm{~mL}$ of the overnight grown bacterial culture was transferred to the flasks, and incubated for 4 days at $31^{\circ} \mathrm{C}$. Then, $0.5 \mathrm{~mL}$ of each culture was added to $10 \mathrm{~mL}$ fish homogenate containing the preservatives as described above. At time 0 and after 3 days, samples were withdrawn and treated as previously described to enumerate bacterial cells. For control experiment, $0.5 \mathrm{~mL}$ of the overnight grown bacterial culture was transferred to $10 \mathrm{~mL}$ fish homogenate alone and incubated for 4 days at $31^{\circ} \mathrm{C}$. Then, $0.5 \mathrm{~mL}$ of the culture was added to 10 $\mathrm{mL}$ fish homogenate containing the preservatives as described above. At time 0 and after 3 days, samples were withdrawn and treated as previously described to enumerate bacterial cells.

\section{Statistical analysis}

Experiments were done four times with consistent results, the values presented are the mean values. To determine the significant differences $(p<0.05)$, student's t-test was used.

\section{RESULTS AND DISCUSSION}

Effect of pretreatment with allura red or tartrazine on growth of $E$. coli in the tested preservatives

Pretreatment with allura red (AR), tartrazine $(T A)$, or nutrient broth alone ( control experiment) before exposure for 1 day to nutrient broth containing ascorbic acid (1\%) greatly reduced 
Table 1. Effect of pre incubation for $4 d$ in nutrient broth containing allura red $(A)$ or nutrient broth containing tartrazine (B) on growth of $E$. coli in nutrient broth containing preservatives

\begin{tabular}{lccc}
\hline & \multicolumn{3}{c}{$\mathbf{A}$} \\
$\begin{array}{l}\text { Exposure time to } \\
\text { the preservative(d) }\end{array}$ & $\mathrm{NB}+20 \% \mathrm{NaCl}$ & $\mathrm{NB}+1 \%$ ascorbic acid & $\mathrm{NB}+0.5 \%$ citric acid \\
\hline 0 & 5.79 & 5.4 & 5.8 \\
1 & $3.4(-2.39)$ & $1.6(-3.8)$ & $3.6(-2.2)$ \\
3 & $1.3(-4.49)$ & 0 & 0 \\
\hline & & $\mathbf{B}$ & \\
Exposure time to & $\mathrm{NB}+20 \% \mathrm{NaCl}$ & $\mathrm{NB}+1 \%$ ascorbic acid & $\mathrm{NB}+0.5 \%$ citric acid \\
the preservative (d) & 6.41 & 6.1 & 6.2 \\
\hline 0 & $4.11(-2.3)$ & $2.1(-4)$ & $3.32(-2.88)$ \\
1 & $1.41(-5)$ & 0 & 0 \\
\hline
\end{tabular}

Numbers in parenthesis represent: $\log \mathrm{CFU} / \mathrm{ml}$ at time $0-\log \mathrm{CFU} / \mathrm{ml}$ at time $1 \mathrm{~d}$ or $3 \mathrm{~d}$.

- : indicates decrease in growth; $d$ : days

Table 2. Effect of pre incubation for $4 \mathrm{~d}$ in nutrient broth alone on growth of $E$. coli in nutrient broth containing preservatives

\begin{tabular}{lccc}
\hline \multirow{2}{*}{$\begin{array}{l}\text { Exposure time to } \\
\text { the preservative }(\mathrm{d})\end{array}$} & $\mathrm{NB}+20 \% \mathrm{NaCl}$ & $\mathrm{NB}+1 \%$ ascorbic acid & $\mathrm{NB}+0.5 \%$ citric acid \\
\cline { 2 - 4 } 0 & 6.56 & 6.2 & 6.3 \\
1 & $4.32(-2.24)$ & $2.65(-3.55)$ & 0 \\
3 & 0 & 0 & 0 \\
\hline
\end{tabular}

Numbers in parenthesis represent: $\log \mathrm{CFU} / \mathrm{ml}$ at time $0-\log \mathrm{CFU} / \mathrm{ml}$ at time $1 \mathrm{~d}$ or $3 \mathrm{~d}$.

- : indicates decrease in growth.

$(p<0.05)$ number of viable cells, number of cells decreased by $3.8,4$, and 3.55 logs, respectively (Table 1 and 2). Pretreatment with AR, TA, or nutrient broth alone before exposure for 3 days to nutrient broth containing ascorbic acid (1\%) killed all cells (Table 1 and 2). The $\mathrm{pH}$ after exposure for 3 days to nutrient broth containing ascorbic acid (1\%) was 3.1, 3.21, and 3.17, respectively. Incubation in AR, TA, or nutrient broth alone before exposure for 1 day to nutrient broth containing citric acid (0.5\%) significantly decreased $(p<0.05)$ number of $E$. coli cells; but cells incubated in AR or TA decreased to a lesser extent than cells incubated in nutrient broth alone (number of cells was decreased by 2.2, 2.88, and 6.3 logs, respectively) (Table 1 and 2). Citric acid can chelate metal ions and may remove $\mathrm{Mg}^{++}$ ions from the outer membrane of Gram- negative bacteria (such as E. coli) which disrupts the cell wall causing death of bacterial cells. E. coli can grow in media containing allura red or tartrazine (unpublished data) and may degrade these dyes; and some of the resultant products may protect $E$. coli from complete inhibition by citric acid (0.5\%). However, incubation in AR, TA, or nutrient broth alone before exposure for 3 days to nutrient broth containing citric acid $(0.5 \%)$ killed all cells (Table 1 and 2).

For growth in nutrient broth containing $\mathrm{NaCl}(20 \%)$, pretreatment with AR, TA, or nutrient broth alone before exposure for 3 days to nutrient broth containing $\mathrm{NaCl}(20 \%)$ decreased $(p<0.05)$ number of cells by $4.49,5$ logs and killed all cells, respectively (Table 1 and 2 ). 
Table 3. Effect of pre incubation for $4 d$ in nutrient broth containing allura red $(A)$ or nutrient broth containing tartrazine (B) on growth of $S$. aureus in nutrient broth containing preservatives

\begin{tabular}{|c|c|c|c|}
\hline \multirow{2}{*}{$\begin{array}{l}\text { Exposure time to } \\
\text { the preservative(d) }\end{array}$} & \multicolumn{3}{|c|}{$\begin{array}{c}\text { A } \\
\log C F U / m l\end{array}$} \\
\hline & $\mathrm{NB}+20 \% \mathrm{NaCl}$ & NB $+0.5 \%$ ascorbic acid & $\mathrm{NB}+0.3 \%$ citric acid \\
\hline 0 & 6.04 & 5.3 & 6.32 \\
\hline 1 & $6.32(+0.28)$ & $3.81(-1.49)$ & $2.64(-3.68)$ \\
\hline \multirow[t]{2}{*}{3} & $6.78(+0.74)$ & $2.3(-3)$ & $1.95(-4.37)$ \\
\hline & & B & \\
\hline \multirow{2}{*}{$\begin{array}{l}\text { Exposure time to } \\
\text { the preservative (d) }\end{array}$} & & Log CFU/ml & \\
\hline & $\mathrm{NB}+20 \% \mathrm{NaCl}$ & NB $+0.5 \%$ ascorbic acid & NB $+0.3 \%$ citric acid \\
\hline 0 & 6.1 & 5.9 & 6.2 \\
\hline 1 & $6.5(+0.4)$ & $3.23(-2.67)$ & $3.99(-2.21)$ \\
\hline 3 & $6.8(+0.7)$ & $2.3(-3.6)$ & $3.66(-2.54)$ \\
\hline
\end{tabular}

Numbers in parenthesis represent: log CFU/ $\mathrm{ml}$ at time $0-\log \mathrm{CFU} / \mathrm{ml}$ at time $1 \mathrm{~d}$ or $3 \mathrm{~d}$.

$+:$ indicates increase in growth.

- : indicates decrease in growth.

Table 4. Effect of pre incubation for $4 \mathrm{~d}$ in nutrient broth alone on growth of $S$. aureus in nutrient broth containing preservatives

\begin{tabular}{lccc}
\hline $\begin{array}{l}\text { Exposure time to } \\
\text { the preservative }(\mathrm{d})\end{array}$ & $\mathrm{NB}+20 \% \mathrm{NaCl}$ & $\mathrm{NB}+0.5 \%$ ascorbic acid & $\mathrm{NB}+0.3 \%$ citric acid \\
\hline 0 & 6.69 & 6.57 & 6.97 \\
1 & $7.60(+0.91)$ & $5.38(-1.19)$ & 0 \\
3 & $7.79(+1.1)$ & $3.5(-3.07)$ & 0 \\
\hline
\end{tabular}

Numbers in parenthesis represent: $\log \mathrm{CFU} / \mathrm{ml}$ at time $0-\log \mathrm{CFU} / \mathrm{ml}$ at time $1 \mathrm{~d}$ or $3 \mathrm{~d}$.

+ : indicates increase in growth;

- : indicates decrease in growth.

Similar results were obtained for pretreatment of $E$. coli in fish homogenate containing $A R$, fish homogenate containing TA, or fish homogenate alone before exposure to ascorbic acid (1\%), citric acid $(0.5 \%)$, or $\mathrm{NaCl}(20 \%)$ (data not shown).

Effect of pretreatment with allura red or tartrazine on growth of $S$. aureus in the tested preservatives

The logs of number of cells of $S$. aureus pretreated with allura red (AR) or tartrazine $(T A)$, then subjected to growth in nutrient broth containing preservatives are shown in Table 3.Pretreatment with AR or TA before exposure for 3 days to nutrient broth containing ascorbic acid $(0.5 \%)$ greatly reduced $(p<0.05)$ number of viable cells, number of cells decreased by 3 and 3.6 logs, respectively(Table 3). Logs of number of cells of $S$. aureus incubated in nutrient broth alone before exposure to preservatives is shown in Table 4. The decrease in log number of viable cells after exposure for 3 days to nutrient broth containing ascorbic acid $(0.5 \%)$ was nearly similar to that observed when cells were pretreated with AR or TA before exposure to the preservatives.

For exposure for 3 days to nutrient broth containing citric acid $(0.3 \%)$ after pretreatment with AR or TA, number of cells of $S$. aureus decreased by 4.37 and 2.54 logs, respectively (Table 3). In control experiment (incubation in nutrient broth alone before exposure to preservatives), all cells of $S$. aureus were killed after exposure for $3 d$ to nutrient broth containing citric acid (0.3\%) (Table 4). Citric acid decreases $\mathrm{pH}$ and chelates metal ions 8 which are needed 
for synthesis of enzymes and other components of Gram positive bacteria (such as S. aureus). Because $S$. aureus can grow in media containing allura red or tartrazine (unpublished data), some of the resultant products may protect bacterial cells grown in AR or TA from complete inhibition by citric acid (0.3\%). However, application of higher concentration of citric acid may prevent growth of S. aureus.

For exposure for 3 days to nutrient broth containing $\mathrm{NaCl}$ (20\%) after pretreatment with $A R, T A$, or nutrient broth alone, number of cells increased by $0.74,0.7$ and 1.1 logs, respectively (Table 3 and 4). S. aureus is one of the osmotolerant bacteria and can survive in high concentrations of sodium chloride. ${ }^{9}$ However, pretreatment with AR or TA did not increase its tolerance to sodium chloride.

Similar results were obtained for pretreatment of $S$. aureus in fish homogenate containing $A R$, fish homogenate containing $T A$, or fish homogenate alone before exposure to ascorbic acid $(0.5 \%)$, citric acid $(0.3 \%)$, or $\mathrm{NaCl}$ (20\%) (data not shown).

\section{CONCLUSION}

Pretreatment of $E$. coli with AR or TA before exposure for 3 days to nutrient broth containing sodium chloride $(20 \%)$ increased its resistance to sodium chloride (20\%). Pretreatment of $S$. aureus with AR or TA before exposure for 3 days to nutrient broth containing citric acid $(0.3 \%)$ increased its resistance to citric acid (0.3\%). This has implications in food and pharmaceutical industries, where AR or TA is used as coloring agent and citric acid or sodium chloride as a preservative.

\section{ACKNOWLEDGMENTS}

None.

\section{FUNDING}

None.

\section{DATA AVAILABILITY}

The datasets generated during and/or analyzed during the current study are available from the corresponding author on reasonable request.

\section{ETHICS STATEMENT}

Not applicable.

\section{REFERENCES}

1. Fallico B, Chiappara E, Arena E, Ballistreri G. Assessment of the exposure to allura red color from the consumption of red juice- based and red soft drinks in Italy. Food additives and Contaminants: Part A. 2011;28(11):15011515. doi: 10.1080/19440049.2011.596166

2. Leo L, Loong C, Ho X, Ramadan M, Suan M, Loke WM. Occurrence of azo food dyes and their effects on cellular inflammatory responses. Nutrition. 2018;46:36-40. doi: 10.1016/j.nut.2017.08.010

3. Khayyat L, Essawy A, Sorour J, Soffar A. Sunset yellow and allura red modulate Bc12 and COX 2 expression levels and confer oxidative stress- mediated renal and hepatic toxicity in male rats. Peer J. 2018;6:e5689. doi: 10.7717/peerj.5689

4. Hennekinne JA, de Buyser ML, Dragacci S. Staphylococcus aureus and its food poisoning toxins: characterization and outbreak investigation. FEMS Microbiol Rev. 2012;36(4):815-836. doi: 10.1111/j.1574-6976.2011.00311.x

5. Crago B, Ferrato C, Drews S, Svenson L, Tyrrell G, Louie M. Prevalence of Staphylococcus aureus and methicillin- resistant $S$. aureus (MRSA) in food samples associated with food borne illness in Alberta, Canada from 2007-2010. Food Microbiol. 2012;32(1):202-205. doi: 10.1016/j.fm.2012.04.012

6. Yang S-C, Lin C-H, Aljuffali I, Fang J-Y. Current pathogenic Escherichia coli food borne outbreak cases and therapy development. Arch Microbiol. 2017;199(6):811-825. doi: 10.1007/s00203-017-1393-y

7. $\mathrm{Abu}$ - Ghazaleh B M. Inhibition of Citrobacter freundii by lactic acid, ascorbic acid, citric acid, Thymus vulgaris extract and $\mathrm{NaCl}$ at $31^{\circ} \mathrm{C}$ and $5^{\circ} \mathrm{C}$. Ann Microbiol. 2006;56(3):261-267. doi: 10.1007/BF03175016

8. Sharma RK. Citric acid. In Naidu AS (ed). Natural Food Antimicrobial Systems. CRC Press, Washington. 2000:689-702.

9. Davidson PM, Taylor TM, Schmidt SE. Chemical preservatives and natural antimicrobial compounds. In: Doyle M P, Beuchat LR, MontvilleTJ (eds). Food Microbiology, Fundamentals and Frontiers. ASM, Washington. 1997:520-536. doi: 10.1128/9781555818463.ch30 